\title{
National scientific production on Burnout Syndrome in ICU nurses and physicians: a bibliometric study
}

Kely Cristina Carneiro de Azevedo ${ }^{1}$

(iD) aqueline Brito Vidal Batista ${ }^{2}$

(iD Roberta Carneiro de Azevedo ${ }^{3}$

(iD) Ana Lucia Belarmino de Araújo ${ }^{4}$

(iD) Eveline de Oliveira Barros ${ }^{5}$

(D) Mariana de Sousa Dantas Rodrigues ${ }^{6}$

\begin{abstract}
1. Nurse, Masters' Student on Nursing at the Post-Graduate Nursing Program (PPGENF/UFPB). Federal University of Paraíba-UFPB, João Pessoa (PB), Brasil 2. Psychologist, Ph.D. in public Health from the Oswaldo Cruz/Fiocruz Foundation. Associate Professor at the Centre for Education of the Federal University of Paraiba and Professor of the Graduate Program in Nursing (PPGENF/CCS/UFPB) 3. Medical Doctor, Resident in Pediatrics at the Institute of Integrative Medicine Professor Fernando Figueira, IMIP, Recife, Pernambuco, Brasil 4. Psychologist, Specialist in Clinical and Educational Psychopedagogy at the University Vale do Acaraú/CE, Instituto Cândida Vargas, João Pessoa (PB), Brasil 5. Nurse, Master's in Nursing at the Post-Graduate Nursing Program (PPGENF/UFPB). University Centre of João Pessoa-UNIPÊ, João Pessoa (PB), Brasil 6. Nurse, Doctorate Candidate on Nursing at the Post-Graduate Nursing Program (PPGENF/UFPB). University Centre of João Pessoa-UNIPÊ, João Pessoa (PB), Brasil
\end{abstract}

http://dx.doi.org/10.1590/1806-9282.65.5.722

\section{SUMMARY}

OBJECTIVE: To analyze the scientific production on Burnout Syndrome in physicians and nurses of ICU in Brazil.

METHOD: Bibliometric study, documentary, with quantitative approach. We selected articles published in Brazil on Burnout Syndrome in the ICUs, in the VHL and Portal Capes, from 2000 to 2018.

RESULTS: 40 articles were identified, predominantly from the Southeast. Prevalence of those published in the Brazilian Journal of Intensive Care and in the Journal of Nursing UFPE online. The B2 Qualis periodical is the most prominent. The most prevalent descriptors were: Intensive Care Units, Burnout Syndrome, Burnout and Professional Exhaustion.

CONCLUSIONS: Nurses are more interested in publishing this issue. Burnout Syndrome studied in intensive physicians would contribute to identifying its prevalence in these professionals.

KEYWORDS: Burnout, Professional. Physicians. Nurses. Intensive Care Units.

\section{INTRODUCTION}

Burnout Syndrome is characterized as a process of responding to an overload caused by the work environment, resulting in exhaustion of the worker. The deterioration of the fundamental relationship that the individual has with their work negatively affects the job performance, interpersonal relationships, and organizational commitment, posing a risk to their health. ${ }^{1.2}$ It is the stress caused by the work activity, which involves negative behavior in relation to users, customers, and work organization and causes emotional and practical damage to the worker and the organization. These negative conducts and attitudes imply directly in a loss of enthusiasm for the work activity. Whereas traditional stress is a per- 
sonal depletion interfering in the life of the individual but is not necessarily related to work ${ }^{3.4}$.

The Ministry of Health considers Burnout Syndrome, or Syndrome of Professional Exhaustion, a disease whose etiologic agent would be a prolonged response to chronic stress that arises from work, and this is the description found in the list of International Statistical Classification of Diseases and Related Health Problems (ICD-10) ${ }^{3}$.

The burnout phenomenon was mentioned for the first time in the United States in the 1970s, in the Freudenberger studies, whose findings showed the harmful physical and mental situation of workers of a Detox Clinic, which included symptoms such as exhaustion, irritation, and cynicism towards patients ${ }^{4}$. In addition, it is also possible to mention Maslach and Jackson ${ }^{5}$, who classified the syndrome in three dimensions: Emotional Exhaustion, Depersonalization and Low Personal Fulfillment.

Thus, some instruments are used to evaluate Burnout Syndrome, among them, the MBI (Maslach Burnout Inventory), drawn up by Christina Maslach and Susan Jackson, which is the most used for the measurement of the syndrome. Another instrument employed is the Cesqt (Síndrome de Quemarse por el Trabajo), developed by Gil-Monte et al. ${ }^{6}$, which adds the study of guilt, not previously investigated in the MBI.

Burnout Syndrome is defined as a response to chronic stress associated with work and consists of four dimensions: Work Illusion, Psychic Wear, Indolence and Guilt, thereby establishing two profiles ${ }^{6}$. Profile 1 represents a moderate form of malaise; profile 2 represents the harmed state due to the syndrome, with the addition of a guilt feeling.

The subject of burnout has been the object of research in various countries and is considered a global problem. Therefore, the frequency and distribution of Burnout Syndrome have become something of global concern, which is why it has been the object of research. In Brazil, according to surveys by the Isma-BR (International Stress Management Association in Brazil) ${ }^{7}$. 32\% of workers suffer from Burnout Syndrome (devastating level of stress), with similar proportions to the United Kingdom. It should also be pointed out that in Germany, even with a reduced workload among the developed countries, $8 \%$ of the workforce shows signs of burnout. In this context, mental illnesses associated with work rank third among the reasons why Brazilian workers receive disability insurance from INSS ${ }^{8}$.
In the context of Brazil, in 1987, the cardiologist Hudson Hubner France published a paper on Burnout Syndrome, the subject started to be discussed ${ }^{9}$. Accordingly, research showed the prevalence of the syndrome among physicians and nurses ${ }^{10-12}$, among whom the presence of this phenomenon is critical, being observed in $23.1 \%$ of doctors, with a score of high degree.

Health professionals, due to their need of keeping direct contact with their clients, are more vulnerable to exhaustion through work ${ }^{13}$. Other studies $^{14.15}$ add that nurses in Intensive Care Units (ICU), due to the tense and exhausting nature of their work activities, are in a position of vulnerability to occupational stress. Moreover, they also point out that the professional intensivists tend to suffer from stressors linked to the environment, the number of work hours, and the high degree of demands related to their skills and abilities, all of which can cause physical and/or psychological illness.

Thus, it should be noted that the hospital environment constitutes a peculiar site to the occurrence of burnout, in view of its very nature, which heightens occupational stressors ${ }^{16}$. ICU is no different, especially for professionals who work there.

In this context, this study sought to answer the following question: what scientific productions available in online journals address Burnout Syndrome in physicians and nurses in Intensive Care Units in the national context? In this perspective, this research has the objective to analyze the scientific production on the Burnout Syndrome in physicians and nurses in Intensive Care Units in Brazil.

\section{METHODS}

This is a bibliometric study with a quantitative and documental approach. The bibliometric method is defended for its functionality in the analysis of science universally, and the long period of time it investigates, by means of databases of citations, allows for a multidisciplinary investigation of the social and cognitive changes in science ${ }^{17}$, with the possibility to pinpoint indicators of scientific production in different areas and themes.

For the preparation of this study, we selected articles that focused primarily on the phenomenon of Burnout Syndrome in Intensive Care Units, on the following online libraries: Biblioteca Virtual de Saúde and Capes Portal. The data collection took place in July 2018. 
The search for articles in the databases was performed using the health care terminology available in the Medical Subject Headings (MeSH), and the terms discussed among the keyword in Health Sciences (DeCS) were subsequently consulted, with the keywords: Burnout, Professional; Physicians; Nurses; and Intensive Care Units combined with the Boolean operator "and" to improve the search and select the studies in accordance with objective of this research.

To select the sample, we adopted the following inclusion criteria: publications in the form of articles, with free-access full texts, available online, from 2000 to 2018, which addressed Burnout Syndrome in doctors and nurses from Care Units in Brazil. In the initial stage, we retrieved 48 publications; then eight studies were excluded because only their abstracts were available. The study sample consisted of 40 articles, organized according to the databases in which they were located.

The timeline established for the study was justified for two reasons: firstly, it is subsequent to the inclusion of burnout in the ICD 10 list and, consequently, subsequent to its recognition in Brazil as a labor disease by the Decree-Law 6.042/2007 of Social Security in 1999. The second reason relates to the meager number of studies available from earlier periods; therefore, their inclusion would not be meaningful to the results of this research.

In the next step, the data were organized according to the desired variables: year of publication, region, periodical, Qualis Periodical, and keywords. The data were analyzed using descriptive statistical analysis, through the calculation of simple frequency in absolute numbers and percentage of variables, using Microsoft Excel ${ }^{\circledR} 2010$.

A concept map (CM) was prepared from the descriptors of the publications selected and the thematic classes that emerged after the selection of keywords, without hierarchy, and considering only the conceptual thematic affinity between them ${ }^{18}$. Based on this understanding, the conceptual maps are extremely valid as graphic organizers that reproduce knowledge, helping in the learning process, and is of especially high relevance for presenting the keywords of the articles.

\section{RESULTS}

Between 2000 and 2018, 40 articles were found that focused on Burnout Syndrome in ICU physi- cians and nurses and met the predetermined criteria. Of these, $15 \%$ ( 6 articles) were published in 2017 , followed by $12.5 \%$ ( 5 articles) in 2011 and 2013, indicating the years of higher production. Then come the years of 2009 and 2014, each with 10\% (4 articles). The years 2010, 2015 and 2016 had, each, 7.5\% (3 articles); and 2008, 2012, and 2018 produced $5 \%$ of publications (each with two articles). In 2004, there was only one publication (2.5\%). In the years 2000 , 2001, 2002, 2003, 2005, 2006 and 2007, there were no records of publications related to the study.

As for the region where the studies were carried out, it appears that the Southeastern region, with 22 (55.0\%) studies, represents a significant predominance in relation to other regions, whose representations of regional publications were: Northeast, with 12 (30.0\%); South, three (7.5\%), Central-West, two (5.0\%), and North, one (2.5\%). It is noteworthy that

TABLE 1 - DISTRIBUTION OF SCIENTIFIC PRODUCTION ON BURNOUT SYNDROME IN ICUS PHYSICIANS AND NURSES, PER PERIODICALS, BRAZIL, 2000 TO 2018 $(\mathrm{N}=40)$. AUTHOR: KELY C. C. AZEVEDO

\begin{tabular}{|c|c|c|}
\hline Periodical & $\mathrm{N}$ & $\%$ \\
\hline Journal of Nursing UFPE on-line & 05 & 12.5 \\
\hline Revista Brasileira de Terapia Intensiva & 05 & 12.5 \\
\hline Revista Latino-Americana de Enfermagem & 03 & 7.5 \\
\hline Revista de Pesquisa: cuidado é fundamental & 02 & 5 \\
\hline Revista da Escola de Enfermagem da USP & 02 & 5 \\
\hline Revista Brasileira de Enfermagem & 02 & 5 \\
\hline Acta Paulista de Enfermagem & 02 & 5 \\
\hline Trends in Psychology & 01 & 2.5 \\
\hline São Paulo Medical Journal & 01 & 2.5 \\
\hline Revista Texto \& Contexto Enfermagem & 01 & 2.5 \\
\hline Revista Psicologia: Ciência e Profissão & 01 & 2.5 \\
\hline Revista Gaúcha de Enfermagem & 01 & 2.5 \\
\hline Revista de Psicologia & 01 & 2.5 \\
\hline Revista de Enfermagem da UFSM & 01 & 2.5 \\
\hline Revista de Enfermagem Centro Oeste Mineiro & 01 & 2.5 \\
\hline Revista da Universidade Vale do Rio Verde & 01 & 2.5 \\
\hline Revista da Spagesp & 01 & 2.5 \\
\hline Revista da Rede de Enfermagem do Nordeste & 01 & 2.5 \\
\hline Brazilian Medical Association Periodical & 01 & 2.5 \\
\hline Revista Ciências em Saúde & 01 & 2.5 \\
\hline Revista Ciência, Cuidado e Saúde & 01 & 2.5 \\
\hline Revista Brasileira de Educação Médica & 01 & 2.5 \\
\hline Online Brazilian Journal of Nursing & 01 & 2.5 \\
\hline Enfermería Global & 01 & 2.5 \\
\hline Ciência \& Saúde Coletiva & 01 & 2.5 \\
\hline Caderno de Saúde Pública do Rio de Janeiro & 01 & 2.5 \\
\hline Total & 40 & 100 \\
\hline
\end{tabular}


one of the studies addressed five capital cities located in five regions of the country; however, the amount of research on the theme from the North and Central-West regions are still meager.

With respect to the periodicals involved in publications, we found that the Revista Brasileira de Terapia Intensiva and the Revista de Enfermagem da UFPE on-line are the most representative, with $12.5 \%(n=5)$ of publications each, followed by the Revista Latino-Americana, with three publications $7.5 \%(\mathrm{n}=3)$. The heterogeneity of different journals involved is imperative. Thus, we obtained only one study per journal (see Table 1).

In relation to the Qualis Periodical, in accordance with the classifications of journals from the quadrennium 2013-2016, in the area of nursing, we identified that they are distributed in strata, ranging from the highest, A1 with only one publication (3.8\%), to B4, with two publications (7.7\%), respectively, in the following journals: Revista Latino-Americana, Revista
Ciências em Saúde, and Revista da Universidade Vale do Rio Verde. However, it is worth pointing out that the B2 stratum was the most prominent, corresponding to nine studies (34.6\%).

In Table 2 it is possible to verify that, regarding the classification of journals in the area of medicine, the periodical entitled Cadernos de Saúde Pública stood out: its Qualis B2 corresponded to the largest stratum of evaluation among the 26 journals listed in this study.

In relation to the keywords, we observed that the ones used most often in the articles were: Intensive Care Units, Burnout Syndrome, Burnout, and Professional Burnout. From the recognition of the keywords, the concept map was developed (Figure 1).

\section{DISCUSSION}

Considering the scientific production on Burnout Syndrome in various areas of knowledge is in a clear

TABLE 2 - SYNTHESIS OF SCIENTIFIC PRODUCTION ON BURNOUT SYNDROME IN ICUS PHYSICIANS AND NURSES, PER QUALI PERIODICALS IN MEDICINE AND NURSING, BRAZIL, 2000 TO 2018 (N=40). AUTHOR: KELY C. C. AZEVEDO

\begin{tabular}{|c|c|c|}
\hline Qualis Periodicals & Medicine & Nursing \\
\hline Journal of Nursing UFPE on-line & - & B2 \\
\hline Revista Brasileira de Terapia Intensiva & B3 $(I, I I, I I)$ & B2 \\
\hline Revista Latino-Americana de Enfermagem & B3 $(I I, I I I)$ & A1 \\
\hline Revista de Pesquisa: cuidado é fundamental & B4 (II) & B2 \\
\hline Revista da Escola de Enfermagem da USP & B4 $(I I, I I I)$ & A2 \\
\hline Revista Brasileira de Enfermagem & $\mathrm{B} 3(\mathrm{II}, \mathrm{III})$ & A2 \\
\hline Acta Paulista de Enfermagem & B3 (II, III); B5 (I) & A2 \\
\hline Temas em Psicologia & - & B2 \\
\hline São Paulo Medical Journal & B3 $(I, I I, I I)$ & B1 \\
\hline Texto \& Contexto Enfermagem & B3 (II); B4 (I) & A2 \\
\hline Revista Psicologia: Ciência e Profissão & B4 (II) & B2 \\
\hline Revista Gaúcha de Enfermagem & B3 (III); B4 (I, II) & B1 \\
\hline Revista de Psicologia: teoria e prática & $\mathrm{B} 5(\mathrm{I}, \mathrm{II})$ & B3 \\
\hline Revista de Enfermagem da UFSM & - & B2 \\
\hline Revista de Enfermagem Centro Oeste Mineiro (Recom) & - & B2 \\
\hline Revista da Universidade Vale do Rio Verde & $\mathrm{B} 5(\mathrm{II})$ & B4 \\
\hline Revista da Spagesp & - & B3 \\
\hline Revista da Rede de Enfermagem do Nordeste & B4 (II); B5 (III) & B1 \\
\hline Brazilian Medical Association Periodical & $\mathrm{B} 3(\mathrm{I}, \mathrm{II}, \mathrm{III})$ & B1 \\
\hline Revista Ciências em Saúde & - & B4 \\
\hline Ciência, Cuidado e Saúde & $\mathrm{B} 5(\mathrm{II})$ & B2 \\
\hline Revista Brasileira de Educação Médica & B4 (II, III); B5 (I) & B2 \\
\hline Online Brazilian Journal of Nursing & $\mathrm{B} 4(\mathrm{I}, \mathrm{II})$ & B1 \\
\hline Enfermería Global & B4 $(\mathrm{I}, \mathrm{II})$ & B1 \\
\hline Ciência \& Saúde Coletiva & $\mathrm{B} 3(\mathrm{I}, \mathrm{II}, \mathrm{III})$ & B1 \\
\hline Cadernos de Saúde Pública & $\mathrm{B} 2(\mathrm{I}, \mathrm{III}) ; \mathrm{B} 3(\mathrm{II})$ & B1 \\
\hline Total & 26 & 100 \\
\hline
\end{tabular}


expansion, it is noteworthy that, when the study is directed at ICU professionals, the numbers are still small, a phenomenon that has been occurring for nearly two decades (2000 to 2018), the period chosen for this study.

In relation to the year of publication of articles, the data obtained from the analysis of this indicator shows that from 2008, there was publication in every subsequent year. However, the growth curve is inconsistent - at times, the number of published articles increases, other times, it decreases, and we could not find an even pace for its expansion, especially concerning the years 2017, 2013 and 2011.

A study conducted by Silva et al. ${ }^{19}$ showed the prevalence of burnout syndrome in $55.3 \%$ of ICU nurses. Corroborating this finding, in the nursing team that works in the ICU of a school hospital of Minas Gerais, the presence of occupational stress was observed in half the team, as well as in intensivists that showed proportions of burnout near or above $50 \%{ }^{20}$ ${ }^{21}$. Although the investigations indicate the presence of the phenomenon in health professionals, the timeline reveals a still unimpressive number of national studies that focus on the scenario of the ICU.

On this matter, it important to mention a national study ${ }^{22}$ whose evidence indicated a reduced amount of research on burnout in health professionals and identified the need for studies that emphasize preventive and therapeutic measures directed at this problem.

According to the Brazilian geographic regions in which health professionals were investigated, we found that the Southeast region is the one that stands out the most, followed by the Northeast region. On the other hand, the North and Midwest regions have little representation, which could be explained by the poor distribution of ICU beds in Brazil. In this perspective, an analysis of the Federal Council of Medicine ${ }^{23}$, which mapped the distribution of ICU beds per states and capitals, revealed that the Southeast region alone concentrates $54 \%$ of the ICUS in the country; whereas the North region has the lowest proportion, with only $5 \%$ of all ICU beds.

The 40 studies found on this topic are distributed in various journals, and the ones that presented the greatest number of scientific publications were: Revista Brasileira de Terapia Intensiva and Journal of Nursing - UFPE on-line. Then there is the representativeness of the Revista Latino-Americana de Enfermagem.
The larger number of articles published in these journals enabled us to identify that the Revista Brasileira de Terapia Intensiva focuses its studies on research based on discussion, distribution, and promotion of information in this area of knowledge, which is aimed at intensivists. In particular, the name of the magazine already makes it inviting for investigations in Intensive Therapy.

In relation to the journal entitled Journal of Nursing - UFPE online, it is understood that it is an international scientific journal of master's and doctoral programs in Nursing, of the Federal University of Pernambuco. Although it is an online journal, it is located in the Northeast region of Brazil, which ranks in second among the studies selected studies, thus catching our attention to the scientific publications in this journal, in addition to focusing on research aimed at nursing and its team.

The dynamics of the variable analysis of the Qualis Periodical has its great value by projecting and giving visibility to quality scientific production. Qualis grades the quality of articles and other types of production based on the analysis of the quality of the means of publication, i.e., scientific journals, classifying them into eight categories: A1, A2, B1, B2, B3, $\mathrm{B} 4$, B5, and $\mathrm{C}^{24}$.

According to the Qualis Periodical, based on the assessment of the Nursing area, it appears that there was a greater representativity of scientific production in journals classified in category B2; the second Qualis of higher expression was A2. Thus, we can see that the scientific production in this great area of Nursing presents a positive trend of publications in Qualis A, either A1 or A2, although some indicators demonstrate certain known difficulties in publishing in upper strata of Qualis. A survey ${ }^{25}$ confirms the challenges faced by professional nurses to publish in periodicals of quality, affirming that it is necessary not just to conduct research, to develop quality knowledge.

In general, publications on Burnout Syndrome in medical journals indicate a limitation related to quantitative studies and the low level of classification of scientific production from Brazilian postgraduate programs published in journals.

It is important to highlight the variety and similarity of terms when consulting DeCs in relation to the theme Burnout Syndrome. They range from Burnout, Professional Burnout, Professional Wear, Professional Stress, Occupational Stress, Emotional and 
FIGURE 1: CONCEPTUAL MAP PRODUCED FROM THE KEYWORDS OF THE ARTICLES AND THE THEMATIC CLASSES ON BURNOUT SYNDROME IN NURSES AND DOCTORS OF INTENSIVE CARE UNITS (N=40). AUTHOR: KELY C. C. AZEVEDO

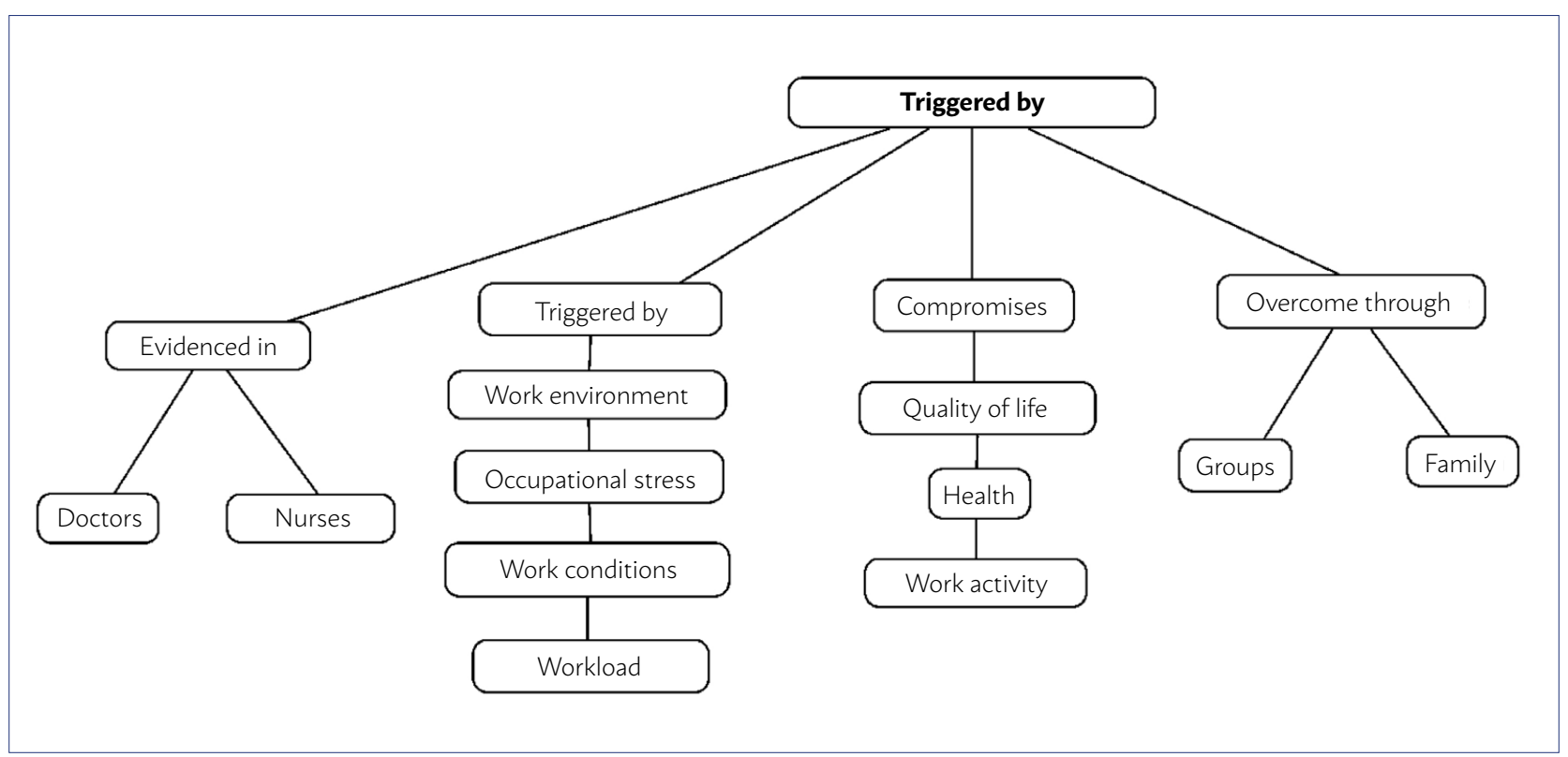

Physical exhaustion, which makes it evident that this issue is in the process of construction. The concept map illustrated in Figure 1 is a graphical representation of concepts that organize themselves, establishing relationships between them and allowing us to reflect on its content ${ }^{26}$.

From the conceptual map, it was possible to identify four thematic groups: professionals affected by the syndrome, factors related to its development, aspects of the professional life that are compromised, and ways to overcome the pathology.

As for the group of professionals affected by Burnout Syndrome, the publications presented the following keywords: health professionals, physicians, nurses, and nursing team. Based on these keywords, studies $^{27,28,29}$ indicate that the nursing work in ICUs faces stressful processes worldwide since the hospital environment is crucial for treating people increasingly diseased and senile ${ }^{30}$. In addition, it has been found that the prevalence of burnout in pediatricians of a public hospital in the South of Brazil was $53.7 \%^{31}$. This result is similar to that of another study that identifies the presence of the syndrome in intensivists of the state of Sergipe, which found that over 40\% of participants were affected by $\mathrm{it}^{32}$.

As for the factors related to the development of Burnout Syndrome in these professionals, the publications used the following keywords: occupational stress, work conditions, and work environment. Cat- egorically, these keywords refer to elements of the organizational model of work. However, the causes of Burnout Syndrome occur at three different levels: individual, organizational, and social. On this subject, studies ${ }^{33.34}$ indicate that burnout is determined by inadequate work organization, which causes an overload, lack of autonomy and support for carrying out tasks. In addition, negative factors in the work environment, such as the lack of structural resources, work organization, and conflicting interpersonal relationships increase the risk of undesirable consequences for health professionals, such as burnout.

In relation to the commitment of some aspects of the professional life of the individual, the following descriptors stood out: quality oflife, work activity, and health. The quality of life at work is determined by individual situations, as well as those which emerge from the working environment itself. In addition, authors ${ }^{35.36}$ argue that work is where people seek excellence in service due to feeling well, in a healthy environment, to accomplish their tasks. It is inferred that the compromise on the quality of life is reached when individuals are expected to reach scores of productivity and primacy, with harmful effects on the body and the mind of public servers.

Quality of life has been the object of research in various areas, especially in the context of health when associated with work. Studies ${ }^{37.38}$ on nurses who work on surgical centers suggest that, in terms 
of health-related quality of life, the physical, emotional and pain domains are the aspects most seriously compromised.

The fourth group of keywords used to portray the ways of tackling Burnout Syndrome in health workers were: groups and family. In this sense, it is necessary to contemplate a definition ${ }^{39}$ that says that effective interventions are those that act positively, causing changes in the individual by following these steps: overcoming the resistance to change and preparing for it to occur; transitioning to a different position and remaining in this the newly changed state. In this context, it is vital to mention a research ${ }^{40}$ that presented an intervention based on group meetings with professional ICU nurses of a university hospital, whose results revealed that groups could help the coexistence of professionals in the work environment. In terms of interpersonal relations, the support of family members is fundamental to mitigate the risk of developing Burnout syndrome in the work environment, since strained relations and conflict are reflected on work. In this context, there are some strategies for intervention, which are grouped into three categories: individual, group, and organizational strategies.

\section{CONCLUSION}

From the bibliometric perspective, the analysis of the scientific production on the Burnout Syndrome in ICU nurses and physicians, based on the databases investigated, showed that nurse researchers have a greater interest in publishing on this theme, in comparison to physicians. Thus, there are some concerns that arise, since studying Burnout Syndrome in intensivists would help to identify their prevalence in these professionals, in addition to being an important indicator of quality in the context of work in health organizations.

It is a fact that the scientific production on Burnout Syndrome in Intensive Care Units has advanced. However, it is considered that there is a low number of publications by medical professionals, hindering the dissemination of knowledge among the medical class. This aspect is relevant to point out the need to develop new studies addressing this phenomenon, especially because it is a major occurrence in the context of mental health.

We found that the Southeast region plays an important role by being the greatest publisher of information in the scientific community, regarding the number of articles published with a focus on burnout in ICU. In addition, the choice of the journal that will feature each discovery is understood to be of great value.

Therefore, considering the vast number of journals available, those who stood out had a though out approach, especially in regards of the scope of the subject (intensive care), with greater visibility in the universe of nursing. However, although the theme studied focuses on the psychosocial nature of the impacts caused, in respect to the Qualis Periodical, the discussions are often not able to be published in journals of greater prominence.

The contribution of this study suggests an attention to the development of more complex research on Burnout Syndrome in the context of Intensive Care Units, which has affected comprehensively Brazilian health workers, especially nurses and intensivists.

\section{RESUMO}

OBJETIVO: Analisar a produção científica sobre a Síndrome de Burnout em médicos e enfermeiros de UTI no Brasil.

MÉTODO: Estudo bibliométrico, documental, com abordagem quantitativa. Foram selecionados artigos publicados no Brasil sobre a Sindrome de Burnout nas UTIs, na BVS e Portal Capes, entre 2000 e 2018. Foi elaborado um mapa conceitual de modo a organizar o eixo temático.

RESULTADOS: Foram identificados 40 artigos, predominantemente do Sudeste. Prevaleceram os publicados na Revista Brasileira de Terapia Intensiva e na Revista de Enfermagem UFPE on-line. O Qualis periódico B2 é o de maior destaque. Os descritores encontrados com maior prevalência foram: Unidades de Terapia Intensiva, Síndrome de Burnout, Burnout e Esgotamento Profissional.

CONCLUSÕES: Enfermeiros apresentam maior interesse em publicar nessa temática. A Síndrome de Burnout estudada em médicos intensivistas contribuiria para identificar a sua prevalência nesses profissionais.

PALAVRAS-CHAVE: Esgotamento profissional. Médicos. Enfermeiras e enfermeiros. Unidades de Terapia Intensiva. 


\section{REFERENCES}

1. Maslach C, Leiter MP, Jackson SE. Making a significant difference with burnout interventions: researcher and practitioner collaboration. J Organiz Behav. 2012;33(2):296-300.

2. Singh P, Suar D, Leiter MP. Antecedents, work-related consequences, and buffers of job burnout among Indian software developers. J Leader Organiz Stud. 2011;19(1):83-104.

3. Brasil. Ministério da Saúde. Organização Pan-Americana de Saúde. Doenças relacionadas ao trabalho: manual de procedimentos para os serviços de saúde. Brasília: Ministério da Saúde; 2001.

4. Olmedo Montes M. Reseña de: Buendía Vidal, José. Estrés laboral y salud. Madrid: Biblioteca Nueva; 1998. Rev Psicopat Psicol Clín. 1998;3(1):73-6.

5. Maslach C, Jackson SE. The measurement of experienced burnout. J Occup Behav. 1981;2:99-113.

6. Gil-Monte PR, Carlotto MS, Câmara SG. Validação da versão brasileira do "Cuestionario para la evaluación del síndrome de quemarse por el trabajo" em professores. Rev Saúde Pública. 2010;44(1):140-7.

7. International Stress Management Association. Burnout: $30 \%$ sofrem do tipo de estresse mais devastador. 2013. [cited 2018 Nov 10]. Available from: http://www.ismabrasil.com.br/artigo/burnout-y-30-sofrem-do-tipo-de-estresse-mais-devastador.

8. Silva Junior IS, Fischer FM. Adoecimento mental incapacitante: benefícios previdenciários no Brasil entre 2008-2011. Rev Saúde Pública. 2014;48(1):186-90.

9. Benevides-Pereira AMT. O estado da arte do burnout no Brasil. Rev Eletrônica InterAção Psy [online]. 2003;1(1):4-11 [cited 2017 Fev 14]. Available from: http://www.saudeetrabalho.com.br/download_2/burnout-benevides.pdf

10. Barbosa GA, Andrade EO, Carneiro MB, Gouveia W. A saúde dos médicos no Brasil. Brasília: Conselho Federal de Medicina; 2007.

11. Ezaias GM, Haddad MCL, Vannuchi MTO. Manifestações psico-comportamentais do Burnout em trabalhadores de um hospital de média complexidade. Rev RENE. 2012;13(1):19-25.

12. Franco GP, Barros ALBL, Nogueira-Martins LA, Zeitoun SS. Burnout em residentes de enfermagem. Rev Esc Enferm USP. 2011;45(1):12-8.

13. Carlotto MS, Câmara SG. Análise da produção científica sobre a síndrome de burnout no Brasil. Psico. 2008;39(2):152-8.

14. Abdo SA, El-Sallamy RM, El-Sherbiny AA, Kabbash IA. Burnout among physicians and nursing staff working in the emergency hospital of Tanta University, Egypt. East Mediterr Health J. 2016;21(12):906-15.

15. Schmidt DRC, Paladini M, Biato C, Pais JD, Oliveira AR. Qualidade de vida no trabalho e burnout em trabalhadores de enfermagem de Unidade de Terapia Intensiva. Rev Bras Enferm. 2013;66(1):13-7.

16. Urbanetto JS, Silva PC, Hoffmeister E, Negri BS, Costa BE, Poli de Figueiredo CE. Workplace stress in nursing workers from an emergency hospital: Job Stress Scale analysis. Rev Lat Am Enfermagem. 2011;19(5):1122-31.

17. Gingras Y. Os desvios da avaliação da pesquisa: o bom uso da bibliometria. Rio de Janeiro: Ed. da UFRJ; 2016. p.148.

18. Cicuto CAT, Correia PRM. Estruturas hierárquicas inapropriadas ou limitadas em mapas Conceituais: um ponto de partida para promover a aprendizagem significativa. Meaningful Learn Rev. 2013;3(1):1-11.

19. Silva JLL, Soares RS, Costa FS, Ramos DS, Lima FB, Teixeira LR. Fatores psicossociais e prevalência da síndrome de burnout entre trabalhadores de enfermagem intensivistas. Rev Bras Ter Intensiva. 2015;27(2):125-33.

20. Andrade RVS, Costa ORS. Estresse ocupacional em profissionais de saúde: um estudo com a equipe de enfermagem da Unidade de Terapia Intensiva - UTI de um Hospital Escola em Minas Gerais. Rev Ciênc Saúde. 2014;4(4):1-11.
21. Tironi MO, Teles JM, Barros DS, Vieira DF, Silva Filho CM, Martins Júnior $D F$, et al. Prevalence of burnout syndrome in intensivist doctors in five Brazilian capitals. Rev Bras Ter Intensiva. 2016;28(3):270-7.

22. Almeida LA, Medeiros IDS, Barros AG, Martins CCF, Santos VEP. Fatores geradores da Síndrome de Burnout em profissionais da saúde. Rev Pesqui Cuid Fundam. 2016;8(3):4623-8.

23. Conselho Federal de Medicina. Estudo inédito do CFM revela que leitos de Unidades de Terapia Intensiva no Brasil são insuficientes e estão mal distribuídos. Brasília: Conselho Federal de Medicina; 2016. [cited 2016 May 21]. Available from: <http://portal.cfm.org.br/index.php?option=com_ content\&view=article\&id=26167:2016-05-16-12-15-52\&catid=3>

24. Trajano MA, Razuck FB, Ceretta CA, Schetinger MC. Evolução da produção científica em Ciência do Solo no Brasil: um olhar sobre o Qualis. Rev. Geografia. 2013;22(3):93-105.

25. Kirchhof ALC, Lacerda MR. Desafios e perspectivas para a publicação de artigos: uma reflexão a partir de autores e editores. Texto Contexto Enferm. 2012;21(1):185-93.

26. Souza NA, Boruchovitch E. Mapas conceituais: estratégia de ensino/ aprendizagem e ferramenta avaliativa. Educ Rev. 2010;26(3):195-218.

27. Santos F.D, Cunha MHF, Robazzi, MLCC, Pedrão LI, Silva LA. O estresse do enfermeiro nas unidades de terapia intensiva adulto: uma revisão da literatura. SMAD. 2010; 6(1):1-16.

28. Pitta A. Hospital, dor e morte como ofício. 3. Ed. São Paulo: Hucitec; 1994.

29. Jaquecs MG, Codo W. Saúde mental e trabalho. Petrópolis: Vozes, 2002.

30. El-Fakhouri S, Carrasco HV, Araújo GC, Frini IC. Epidemiological profile of ICU patients at Faculdade de Medicina de Marília. Rev Assoc Med Bras. 2016;62(3):248-54.

31. Lima FD. Incidência da síndrome de burnout em organização hospitalar pública em Florianópolis, UFSC, 2004. Rev Bras Educ Med. 2007;31:13746.

32. Barros MMS, Almeida SP, Barreto ALP, Faro SRS, Araújo MRM, Faro A Síndrome de burnout em médicos intensivistas: estudo em UTIs de Sergipe. Temas Psicol. 2016;24(1):377-89.

33. Maslach C, Jackson SE, Leiter M. Maslach burnout inventory manual. $3^{\text {rd }}$ ed. Palo Alto: Consulting Psychologist's Press; 1996. p.51.

34. Panunto MR, Guirardello EB. Professional nursing practice: environment and emotional exhaustion among intensive care nurses. Rev Latino-Am Enfermagem. 2013;21(3):765-72.

35. Britto LV, Silva IFF, Florentino RC. Qualidade de vida no trabalho - QVT: uma estratégia competitiva para o aumento da produtividade. Evidência. 2014;10(10):87-97.

36. Mattos CBM. "Vestir a camisa de força": adoecimento psíquico em uma instituição pública na Amazônia [Dissertação]. Porto Velho: Universidade Federal de Rondônia; 2013.

37. Almeida ANF, Gurgel ERS, Silva SR. Qualidade de vida dos profissionais de enfermagem de um centro cirúrgico. Rev Bras Qual Vida. 2014;6(4):21622.

38. Oler FG, lesus AF, Barboza DB, Domingos NAM. Qualidade de vida da equipe de enfermagem do centro cirúrgico. Rev Arq Ciên Saúde. 2005;12(2):102-10.

39. Leiter MP, Maslach C. Interventions to prevent and alleviate burnout. In: Leiter MP, Bakker AB, Maslach C. Current issues in work and organizational psychology. Burnout at work: a psychological perspective. New York: Psychology Press; 2014. p.145-67.

40. Peres RS, Pereira MS, Xavier FTA, Oliveira FM. Compartilhar para conviver: relato de uma intervenção baseada em grupos de encontro para abordagem de estressores ocupacionais. Rev SPAGESP. 2011;12(1):14-21. 